\title{
Technical assistance and seasonality in the diet and production of dairy herds in household agriculture of Western Paraná
}

\author{
Rodrigo Cesar dos Reis Tinini ${ }^{1}$, Maximiliane Alavarse Zambom ${ }^{1}$, Magali Soares dos Santos \\ Pozza $^{1}$, Tatiane Fernandes ${ }^{1}$, Deise Dalazen Castagnara ${ }^{1}$, Ana Cláudia Radis ${ }^{1}$, Geraldo Tadeu \\ dos Santos ${ }^{2}$, Leslié Defante ${ }^{1}$
}

\footnotetext{
${ }^{1}$ Universidade Estadual do Oeste do Paraná, Centro de Ciências Agrárias, Marechal Cândido Rondon, PR, Brasil.

${ }^{2}$ Universidade Estadual de Maringá, Departamento de Zootecnia, Maringá, PR, Brasil.
}

\begin{abstract}
The objective of the present study was to characterize the food sources, as well as the composition and quality of milk obtained from household farms of western Paraná State (Brazil) with and without technical assistance during the different seasons. For such, 24 properties were selected, 12 of which only received assistance and technical support. Four milk samples were taken (summer, autumn, winter and spring) to assess the physicochemical composition, somatic cell count and total bacterial count and feed supplied to the animals to assess the chemical composition (crude protein, ash, dry matter and neutral detergent fiber). The data were analyzed in a completely randomized design with a $2 \times 4$ factorial arrangement; the first factor was the presence and absence of technical assistance and the second factor was the four seasons of the year. Due to the dairy tradition of properties in the region, technical assistance had no significant effects on the health and nutritional quality of food, the number of animals, the production, or total bacterial count, which suffered oscillations only depending on the seasons of the year. However, the presence of assistance contributed to reducing somatic cell counts of milk produced and marketed. The technical assistance does not affect the quality of forages and concentrates used or the milk composition; however, it improves the sanitary quality of the milk produced throughout the four seasons of the year in household farms of western Paraná.
\end{abstract}

Key Words: dairy farming, food quality, milk quality

\section{Introduction}

The existence of household farmers is directly related to the preservation of the historical and cultural heritage of the Brazilian rural area. The most recent statistics show that the country accounts for 4.8 million farms, and $85 \%$ are considered family production that generates about 14 million vacancies in rural areas (Zoccal et al., 2005).

The milk production chain is diffused throughout the Brazilian territory, practiced mainly in small farms. This activity represents the sole income of many families, which survive in small properties distributed throughout the national territory (Yamaguchi et al., 2006), but the lack of technical assistance and rural credit hampers the permanence of the producers in this activity.

Milk is a food rich in nutrients; however, it is liable to contamination that can dramatically change its quality and commercial value (Guerreiro et al., 2005). For this reason, among the various quality aspects to be observed by

Received June 21, 2013 and accepted October 1, 2014.

Corresponding author: digotinini@hotmail.com

http://dx.doi.org/10.1590/S1806-92902015000200005

Copyright (C) 2015 Sociedade Brasileira de Zootecnia. This is an Open Access article distributed under the terms of the Creative Commons Attribution Non-Commercial License, which permits unrestricted non-commercial use, distribution, and reproduction in any medium, provided the original work is properly cited. producers and technicians, attention to quality is required from the herd feeding to storage after milking.

One of the paths to be taken to ensure the milk quality and also for development and implementation of public policies that promote the dairy cattle activity is to diagnose the reality of the activity by identifying bottlenecks that limit its growth and technification.

The western Paraná State has a herd with significant genetic potential, a mean yield of 2,701 L/cow/year, leading the region to be the largest milk-producing state (Volpi and Digiovani, 2008); however, many farmers have abandoned the activity, and the production rates and quality are below those that can be obtained.

In this context, the objective of the present study was to determine the influence of technical assistance on the production and quality of milk from properties of household agriculture in the western region of Paraná State, as well as to characterize the food supplied to the dairy herd and its quality throughout the year.

\section{Material and Methods}

The study was conducted from May 2009 to December 2010. The study area includes the western region of Paraná State, Brazil, comprising the following municipalities: 
Diamante do Oeste, Marechal Cândido Rondon, Mercedes, Nova Santa Rosa, Ouro Verde do Oeste, Pato Bragado, Quatro Pontes, Ramilândia, São José das Palmeiras, São Pedro do Iguaçu and Vera Cruz do Oeste.

Twenty-four farms were selected in partnership with the Instituto Paranaense de Assistência Técnica e Extensão Rural (EMATER) and Associação Leite Oeste in which the main agricultural activity was milk production. Also, it was adopted as a criterion that properties were maintained exclusively on family manpower, and that the family income was entirely derived from the property.

Out of the 24 properties studied, 12 were selected in partnership with EMATER, which took into account the location of the properties where the HDI (human development index) is low (about 0.709). Due to the location, these properties received the assistance of technicians, professors and scholars participating in the project. The other 12 properties were selected in partnership with the Associação Leite Oeste, and received no technical assistance.

To obtain the information from producers, data collection related to dairy production systems (SPL) was performed using a semi-structured guide questionnaire, which is composed of directed open and closed questions, in order to meet the producers and characterize their production by using the techniques of data collection and research in SPL (Damasceno et al., 2008).

Four samples of the feed supplied to the animals were taken, one in each season (summer, autumn, winter and spring). For later correlation of the results with the climate conditions, the climate data for the region were monitored by an automatic meteorological station (Figure 1) (Latitude: $24^{\circ} 33^{\prime} 24^{\prime \prime}$; Longitude: $\left.54^{\circ} 3^{\prime} 24^{\prime \prime}\right)$. The properties were located within a radius of $60 \mathrm{~km}$ from the weather station.

Food samples were identified and had their chemical composition determined.

To study the chemical composition, samples were dried and ground, and subjected to laboratory procedures to determine dry matter (DM) according to AOAC (1990), mineral matter $(\mathrm{MM})$ and crude protein $(\mathrm{CP})$ contents according to Silva and Queiroz (2002) and neutral detergent fiber (NDF) according to Van Soest et al. (1991).

Milk samples were collected in each of the seasons. For physicochemical analysis of milk, the collection was made by sampling directly from the cooling tank on the day of milking and packaging in standardized $70-\mathrm{mL}$ bottles using Bronopol (2-bromo 2 nitropropane-1,3-diol) as preservative for analyzing fat, protein, lactose, total solids and somatic cell count (SCC). For total bacterial count (TBC) the samples were placed in standardized 70-mL vials using azidiol as a preservative.
Subsequently, the bottle was deposited in ice coolers to be taken to the laboratory in a period of less than 24 hours after collection to preserve the integrity and the temperature of the milk sample collected.

After the analysis and production of reports on the chemical composition of foods, they were sent to producers and the delivery was performed as an orientated visit with information about the quality of the food as well as the recommendations on the nutritional management of the herd.

For properties that had received technical assistance, it was held together with the delivery of questionnaires, considering the levels of fat $(3.0 \%)$, protein $(2.9 \%)$ and total solids $(8.4 \%)$ regarding milk - an associated food management practice adopted in each property. Requirements elucidation was held for the South, Southeast and Midwest for TBC $(750,000 / \mathrm{mL})$ and SCC $(750,000 / \mathrm{mL})$, reference values for July 2008 in 51 (51 Statement of 2002), performing recommended milking practices when necessary. On the properties with values higher than or equal to IN 51, a sanitary monitoring was performed with a demonstration of the CMT test (California mastitis Test) for the diagnosis of subclinical mastitis, which has a correlation with increase in the SCC and demonstration of the black bottom mug test. Also, training work was conducted with producers through field days, with some items being highlighted such as milk weighing, animal weighing and evaluation of body score, management and hygiene of milking (pre-and post-dipping, milking line, general care during and after milking).

The data were computed and a completely randomized design with a $2 \times 4$ factorial arrangement was used for statistical analysis, the first factor being the presence and

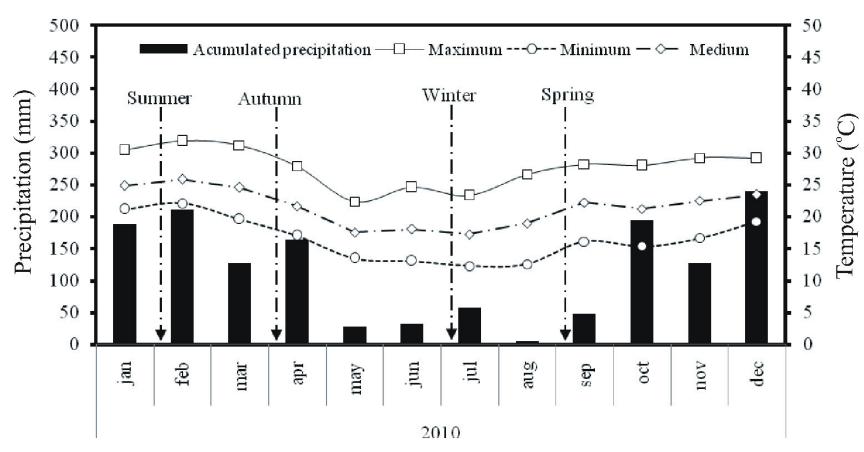

Source: Automatic Climatological Station of Experimental Stations - Unioeste, Marechal Cândido Rondon, PR, Brazil, 2010.

Figure 1 - Climatic conditions during the study with indication of dates of the visits to properties and sampling of food and milk. 
absence of technical assistance, and the second factor the four seasons of the year. After being tabulated, data were subjected to analysis of variance and means were compared by the Tukey test at $5 \%$ probability using the Sisvar 5.3 Build 7.7 statistical program.

\section{Results and Discussion}

The presence or absence of technical assistance did not affect the type and composition of the main ingredients used on the properties assisted during the study. This result is due to the technological level (Fernandes et al., 2004) and agricultural tradition (Paraná, 2010) in the western Paraná.

Even with the reduction in growth rate and DM production of grasses of the Cynodon genus from May to September in the western region of Paraná, this was the predominant forage and feed supplied to animals grazing on all properties visited during all seasons (Table 1). The predominance of the use of such grasses is due to their significant productivity and high nutritive value.

However, with the climatic variation among the seasons, other roughage foods were used, especially Cynodon grass hay (25\% of the properties throughout the year) and corn silage (31.94\% of the properties in autumn, winter and spring, and $20.83 \%$ in summer). In occasional shortages of these main roughage foods, especially in the seasons of spring and summer, some properties used other foods, such as sorghum ( $4.16 \%$ of farms), oats silages and grasses of the genus Cynodon ( $4.16 \%$ of farms), sugarcane ( $4.16 \%$ of holdings) and oat hay ( $4.16 \%$ of holdings). The use of forages conserved as hay and/or silage allows for the storage of surplus forage produced on the property, allowing its use in periods of scarcity of quality forage (Reis Junior et al., 2011).

The use of different alternative forages on the property can compensate for a large part of the costs with feed; however, it requires the producer to strategically plan the availability of these roughage feeds to the animals throughout the seasons (Reis Junior et al., 2011).

Concerning the chemical composition of the pasture supplied to the animals due to the adoption of cultivation and management technologies traditionally adopted in the region (Fernandes et al., 2004), changes occurred only depending on the seasons of the year, with no significance of the presence or absence of technical assistance and the interaction of the studied factors (Table 1). There was a reduction in the nutritional value through the seasons, with increases in the content of DM and reduction in protein content over the samplings (Table 1). For Cynodon there was also an increase in the NDF content (Table 1). The results were expected, since the sampling of Cynodon began in the summer, a period in which the growth of tropical grasses is favored by climatic conditions, and lasted until the winter. The oat pastures were initially sampled in winter, and due to the use of long cycle cultivars such as oats IPR 126, it lasted until the spring.

The chemical composition and the occurrence of mycotoxins in hay of grasses of the genus Cynodon were not affected by the studied factors (Table 2). However, the DM contents showed a lack of appropriate technology for the dehydration of these hays, especially in summer, when they had a DM content of less than $900 \mathrm{~g} / \mathrm{kg}$. This is not considered safe for storage of that roughage food (Calixto Junior et al., 2007). The variations are due to dehydration methods and hay conservation (Jobim et al., 2007) and the different climatic conditions throughout the seasons (Santos et al., 2008).

Significance was found in the seasons for the composition of corn silages (Table 2) in the content of DM, $\mathrm{CP}$ and $\mathrm{MM}$; however, these variations cannot be attributed to climatic conditions, since the silage remains stored for varied periods from one property to another. One of the

Table 1 - Chemical composition of the pastures used in the main household farms in western Paraná throughout the four seasons

\begin{tabular}{|c|c|c|c|c|c|c|c|c|}
\hline & \multicolumn{4}{|c|}{ Season } & \multicolumn{3}{|c|}{ P-value } & \multirow{2}{*}{ CV $(\%)$} \\
\hline & Summer & Autumn & Winter & Spring & TA & $\mathrm{S}$ & $\mathrm{TA} \times \mathrm{S}$ & \\
\hline \multicolumn{9}{|c|}{ Cynodon grasses } \\
\hline Dry matter (\%) & $233.4 \mathrm{c}$ & $295.3 b$ & $347.7 \mathrm{a}$ & $362.7 \mathrm{a}$ & 0.518 & 0.000 & 0.608 & 9.51 \\
\hline Crude protein $(\%)$ & $165.9 \mathrm{a}$ & $161.6 \mathrm{a}$ & $132.3 b$ & $86.7 \mathrm{c}$ & 0.773 & 0.000 & 0.547 & 10.31 \\
\hline Mineral matter $(\%)$ & $77.3 \mathrm{bc}$ & $75.6 \mathrm{c}$ & $106.9 \mathrm{a}$ & $83.9 b$ & 0.285 & 0.000 & 0.853 & 19.44 \\
\hline Neutral detergent fiber $(\%)$ & $760.2 b$ & $791.8 \mathrm{ab}$ & $810.4 b$ & $883.2 \mathrm{a}$ & 0.410 & 0.000 & 0.484 & 15.21 \\
\hline \multicolumn{9}{|c|}{ Avena grasses } \\
\hline Dry matter (\%) & - & $235.2 \mathrm{c}$ & $255.5 b$ & $288.7 \mathrm{a}$ & 0.831 & 0.000 & 0.355 & 4.07 \\
\hline Crude protein $(\%)$ & - & $149.2 \mathrm{a}$ & $143.7 b$ & $129.8 \mathrm{c}$ & 0.058 & 0.000 & 0.251 & 5.91 \\
\hline Mineral matter $(\%)^{\mathrm{ns}}$ & - & 96.6 & 83.0 & 98.0 & 0.735 & 0.398 & 0.427 & 22.12 \\
\hline Neutral detergent fiber $(\%)^{\mathrm{ns}}$ & - & 646.4 & 633.8 & 650.8 & 0.456 & 0.656 & 0.647 & 6.19 \\
\hline
\end{tabular}

TA - technical assistance; $\mathrm{S}$ - season; TA $\times$ S - technical assistance $\times$ season interaction; $\mathrm{CV}$ - coefficient of variation; ns - not significant. Means followed by different letters in the row differ statistically by the Tukey test (5\%). 
main factors that interfere with the quality of corn silage is the management applied to corn intended for ensiling. On properties that have a high demand for corn grain for animal feeding, or even when the corn has its price marketing more valuable, crops for production of silage and animal feed are those that would provide the lowest grain yield. These crops include those harmed by frost, drought or even those implemented and conducted under lower technological levels. Because silaging aims at preserving the nutrients of the material in nature, when the ensiled material has impaired nutritional value, its silage will consequently have a low nutritional value.

The DM content observed in the silage is appropriate, since it is above $250 \mathrm{~g} / \mathrm{kg}$, the lower limit set to obtain suitable fermentation with reduced losses by the effluents production (McDonald et al., 1991). It is also within the range of 30 to $35 \%$ recommended by Tomich et al. (2004). Similarly, the content of CP obtained in summer, spring and autumn are within the range of values usually observed in corn silage, ranging from 60 to $90 \mathrm{~g} / \mathrm{kg}$ (Melo et al., 1999). The lower CP content observed in the silage during the winter period is due to the features of the crop corn used in making these silages, which is grown during the "off season" (summer/autumn) after the summer crops and often under low technology due to the high risks for the culture deployment in the region (Gonçalves et al., 2002).

In corn silages there was no significance of the studied factors on the occurrence of mycotoxins (Table 2). The study of the occurrence of mycotoxins in processed or stored foods is relevant given the detrimental effects to the health of animals triggered by these toxic compounds, mainly young ruminants (Munck et al., 1984; Wittenberg et al., 1996). Thus, in addition to the nutritional quality, the sanitary quality of foods also deserves attention, in order to ensure food safety and animal welfare (Domingues, 2009).

The occurrence of mycotoxins in Cynodon hay was practically nil, but the existence of significant amounts of mycotoxins was detected in the corn silage (Table 2). The results observed for hay reflect the proper environment of food storage in the properties, away from moisture and locations covered and protected from rain and insolation. As for silage, the reality is quite the opposite. The conditions that induce the occurrence of mycotoxins are frequently found on the properties, including delays in bins loading, ineffective sealing and inappropriate unloading; the vast majority of problems arises from the lack of planning and proper sizing of crops, plants and animals consumption.

There was a great diversity in the foods used on the properties; however, with predominance, in all seasons, of the use of soybean meal, trade feed and feed prepared on the property itself, such that these foods were found on $35.41 \%, 21.87 \%$ and $34.37 \%$ of the properties, respectively. Wheat bran and corn, in turn, were found on $20.83 \%$ and $28.12 \%$ of the properties, respectively, regardless of the presence or absence of technical assistance. The wet grain silage was found being used as concentrate food on some properties in all seasons of the year in which visits were paid to the properties.

The use of diets prepared on the farm was observed on many of the properties (34.37\%). The adoption of this technique is promising from the perspective of cost reduction regarding the food safety of animals. When making the feed on the property, the farmers know the origin and condition of the ingredients used in its composition, which besides assuring the quantities of each ingredient, also ensures the supply of healthy foods with good quality to the animals.

Table 2 - Chemical composition and occurrence of mycotoxins in the main preserved roughage foods used on household farms in western Paraná throughout the four seasons

\begin{tabular}{|c|c|c|c|c|c|c|c|c|}
\hline & \multicolumn{4}{|c|}{ Season } & \multicolumn{3}{|c|}{ P-value } & \multirow{2}{*}{$\mathrm{CV}(\%)$} \\
\hline & Summer & Autumn & Winter & Spring & TA & $\mathrm{S}$ & $\mathrm{TA} \times \mathrm{S}$ & \\
\hline \multicolumn{9}{|c|}{ Cynodon hay } \\
\hline Dry matter $(\mathrm{g} / \mathrm{kg})^{\mathrm{ns}}$ & 811.3 & 904.5 & 908.9 & 907.7 & 0.302 & 0.113 & 0.052 & 12.61 \\
\hline Crude protein $(\mathrm{g} / \mathrm{kg})^{\mathrm{ns}}$ & 101.4 & 126.7 & 116.4 & 146.5 & 0.537 & 0.059 & 0.964 & 45.15 \\
\hline Mineral matter $(\mathrm{g} / \mathrm{kg})^{\mathrm{ns}}$ & 76.7 & 69.0 & 83.0 & 66.9 & 0.292 & 0.807 & 0.889 & 20.95 \\
\hline Neutral detergent fiber $(\mathrm{g} / \mathrm{kg})^{\mathrm{ns}}$ & 795.3 & 857.4 & 870.3 & 871.6 & 0.269 & 0.798 & 0.163 & 9.21 \\
\hline Aflatoxins (ppm) & 0.096 & 0.255 & - & - & 0.185 & 0.508 & 0.997 & 12.44 \\
\hline Zearalenone (ppb) & 0.000 & 0.267 & - & - & 0.301 & 0.632 & 0.686 & 39.59 \\
\hline \multicolumn{9}{|c|}{ Corn silage } \\
\hline Dry matter (\%) & $323.1 b$ & $378.8 \mathrm{a}$ & $350.0 \mathrm{ab}$ & $370.1 \mathrm{a}$ & 0.491 & 0.005 & 0.908 & 11.52 \\
\hline Crude protein (\%) & $65.8 \mathrm{ab}$ & $84.7 \mathrm{a}$ & $56.0 \mathrm{~b}$ & $77.5 \mathrm{ab}$ & 0.018 & 0.065 & 0.054 & 31.74 \\
\hline Mineral matter (\%) & $59.7 \mathrm{a}$ & $41.1 \mathrm{~b}$ & $60.4 \mathrm{a}$ & $48.1 \mathrm{ab}$ & 0.646 & 0.002 & 0.126 & 27.62 \\
\hline Neutral detergent fiber $(\%)^{\mathrm{ns}}$ & 668.3 & 648.4 & 646.9 & 690.8 & 0.055 & 0.416 & 0.056 & 11.76 \\
\hline Aflatoxins (ppm) & 0.187 & 0.386 & - & - & 0.372 & 0.433 & 0.405 & 22.69 \\
\hline Zearalenone (ppb) & 5.70 & 6.40 & - & - & 0.665 & 0.832 & 0.549 & 14.78 \\
\hline
\end{tabular}

TA - technical assistance; S - season; TA $\times$ S - technical assistance $\times$ season interaction; $\mathrm{CV}$ - coefficient of variation; ns - not significant.

Means followed by different letters in the row differ statistically by the Tukey test (5\%). 
The chemical composition of soybean meal had only the contents of $\mathrm{CP}$ and $\mathrm{MM}$ changing depending on the seasons (Table 3). Despite variations, the obtained values are similar to those found by Rieger et al. (2008), who studied the composition of soybean meals of the West and Southwest regions of Paraná, and Zambom et al. (2001), who studied the nutritional value of feed for ruminants in the North West of Paraná. The CP, however, showed variations depending on the seasons, but these variations are not due specifically to climatic conditions, but rather to the origin of the grains used for bran production (Grieshop et al., 2003) and the shell proportion added to the bran (Zambom et al., 2001).

The composition and occurrence of mycotoxins in wheat bran, corn, commercial feed and feed prepared on the properties were not affected by the studied factors (Table 3). The observed values are consistent with those listed in tables of nutritional values of foods, such as Valadares Filho et al. (2000) and Rostagno et al. (2005).

Despite the lack of significance, the numerical values obtained for the composition and occurrence of mycotoxins in corn and the feed prepared on the property associated with the high coefficients of variation observed (Table 3) show the absence or inefficiency of technical assistance on the properties. Feed and food contamination by mycotoxins can vary according to environmental conditions and processing, showing such high coefficients of variation among the evaluated samples. The corn grain composition can be altered by the technology used in its cultivation, while the quality of the diet prepared on the property is directly affected by the quality of ingredients used. Both feeds and ingredients have their quality affected by the method of preservation and storage environment (Domingues, 2009).

The quantification of mycotoxins is relevant from the sanitary point of view not only for animals but also for consumers of dairy products. When contaminating the animals through consumption of contaminated food, mycotoxins are transferred to the products of animal origin such as milk or meat, and consequently impair the health of human consumers (Bruerton, 2001).

According to Jobim et al. (2003), even in countries with high technology for production and storage of corn, losses by the presence of mycotoxins are high; this determines the need for constant vigilance in the production and utilization of dry or ensiled corn grain to achieve greater competitiveness and returns to producers.

Overall, the incidence of mycotoxins found can be considered high. According to data from the Food and Agriculture Organization (FAO, 1996), the allowable limits for zearalenone have not yet been established in Brazil.
Uruguay allowed a maximum of $200 \mathrm{mg} / \mathrm{kg}$ for corn and barley. In Austria the limits allowed to feed for swine dams are $50 \mathrm{mg} / \mathrm{kg}$; France, $200 \mathrm{mg} / \mathrm{kg}$ for cereals and vegetable oils in general; and Italy, $100 \mathrm{mg} / \mathrm{kg}$ for cereals.

In the case of aflatoxin, the maximum limit allowed for grains varies according to the laws of each country. The limits allowed in Brazil for food intended for human consumption is $20 \mathrm{mg} / \mathrm{kg}$ for shelled corn (whole, broken, crushed and ground), flour or meal of corn, groundnuts and derivatives (ANVISA, 2002). The Ministry of Agriculture, Livestock and Supply of Brazil adopts the limit of $50 \mathrm{mg} / \mathrm{kg}$ for food intended for animal consumption (direct ingestion or feed raw material) (Brasil, 2002).

The values of mycotoxin analysis are below the reference means suggested by ANVISA and FAO; however, according to Rupollo (2006), variations in values per season can be characterized by the storage means and the incidence of precipitation. The main factors that favor the development of fungi during storage of grains are humidity, temperature, storage period, the initial level of contamination, impurities, insects, intergranular $\mathrm{CO}_{2}$ concentration, and physical and sanitary conditions of the grains (Lazzari, 1997). Under favorable environmental conditions of moisture and temperature, the fungal spores germinate developing hyphae, which infest grains, feed and other substrates (Prado et al., 1991).

The wet grain silage had only the MM content changed by the seasons (Table 3 ). These changes were due to the same reasons of the previously described changes caused in the whole plant silage. The use of this concentrate food with high humidity as feed began in Paraná, especially in swine farms (Henrique et al., 2007), but its use is now widespread on dairy farms in the region.

The number of lactating animals on properties assisted by the project changed with the seasons (Table 4), and it was higher on properties that did not receive technical assistance (28) compared with those that received (12). In the course of the seasons there was reduction in the number of animals in the spring (Table 4). This reduction is due to the scarcity of forage occurring in this period due to the occurrence of a winter with low rainfall (Figure 1). According to Costa et al. (2012), the productivity of forage grasses results from the continuous emission of leaves and tillers, important processes for the restoration of leaf area after cutting or grazing that ensures its survival, and the morphogenesis of a grass during its vegetative growth can be strongly influenced by environmental conditions (temperature, light, water and soil fertility).

During the winter period, producers managed to feed the herd with the stock of preserved forage (hay and silage) 
prepared traditionally. However, the development of winter pastures was harmed by the prolonged drought, as well as the regrowth of tropical pastures, making many producers stop the lactation of animals early or even commercialize some of animals on the properties to reduce feed intake and obtain income to purchase food for the other animals.

The total production per property followed a trend similar to that observed for the number of animals (Table 4), but with a drastic reduction in the spring due to the unfavorable weather conditions for the development of grasses (Figure 1), the main food source for the livestock.

The highest number of animals, as well as the highest total production on properties that did not receive assistance is due to the fact that technical assistance is precisely targeted to small properties in order to intensify the development of the activity. On traditional properties, even those of families, technical assistance is often not required due to tradition and the level of technification, which lead farmers to believe that technical assistance is unnecessary.

The daily production per animal remained constant throughout the seasons (Table 4); however, it was higher on the properties without assistance (15.93 kg/animal/day) as compared with those which received technical assistance (12.64 kg/animal day), revealing the specialization in this activity on some properties of the West. These numbers are due to the existing livestock tradition in the region (Paraná, 2010). Despite the differences, the observed yields are above the national mean of about $7.0 \mathrm{~kg} / \mathrm{animal} /$ day in 2011 (Bittar et al., 2011).

Regarding the milk composition, fat and protein were not affected by the studied factors (Table 4). Although there was no statistical variation, it can be seen that in

Table 3 - Chemical composition and occurrence of mycotoxins in major concentrate food used in household farms in western Paraná throughout the four seasons of the year 2010

\begin{tabular}{|c|c|c|c|c|c|c|c|c|}
\hline & \multicolumn{4}{|c|}{ Season } & \multicolumn{3}{|c|}{ P-value } & \multirow{2}{*}{ CV $(\%)$} \\
\hline & Summer & Autumn & Winter & Spring & TA & $\mathrm{S}$ & $\mathrm{TA} \times \mathrm{S}$ & \\
\hline \multicolumn{9}{|c|}{ Soybean bran } \\
\hline Dry matter $(\mathrm{g} / \mathrm{kg})^{\mathrm{ns}}$ & 889.1 & 888.7 & 896.6 & 907.3 & 0.073 & 0.752 & 0.538 & 1.69 \\
\hline Crude protein $(\mathrm{g} / \mathrm{kg})$ & $499.3 \mathrm{ab}$ & $444.2 b$ & $524.3 \mathrm{a}$ & $511.6 \mathrm{a}$ & 0.043 & 0.273 & 0.730 & 9.50 \\
\hline Mineral matter $(\mathrm{g} / \mathrm{kg})$ & $68.9 \mathrm{ab}$ & $52.6 \mathrm{c}$ & $70.9 \mathrm{a}$ & $60.3 \mathrm{bc}$ & 0.000 & 0.423 & 0.145 & 10.05 \\
\hline Aflatoxins $(\mathrm{ppm})^{\mathrm{ns}}$ & 0.112 & 0.037 & - & - & 0.325 & 0.819 & 0.874 & 52.44 \\
\hline Zearalenone $(\mathrm{ppb})^{\mathrm{ns}}$ & 3.544 & 1.800 & - & - & 0.396 & 0.359 & 0.257 & 21.72 \\
\hline \multicolumn{9}{|c|}{ Wheat bran } \\
\hline Dry matter $(\%)^{\mathrm{ns}}$ & 859.5 & 898.2 & 868.8 & 911.1 & 0.069 & 0.327 & 0.066 & 3.79 \\
\hline Crude protein $(\%)^{\mathrm{ns}}$ & 176.9 & 195.8 & 190.3 & 187.2 & 0.912 & 0.913 & 0.135 & 20.61 \\
\hline Mineral matter $(\%)^{\mathrm{ns}}$ & 53.8 & 41.3 & 73.8 & 47.5 & 0.217 & 0.593 & 0.515 & 38.18 \\
\hline Aflatoxins (ppm) $)^{\mathrm{ns}}$ & 0.078 & 0.130 & - & - & 0.580 & 0.310 & 0.985 & 59.11 \\
\hline Zearalenone $(\mathrm{ppb})^{\mathrm{ns}}$ & 4.633 & 4.105 & - & - & 0.915 & 0.511 & 0.895 & 82.27 \\
\hline \multicolumn{9}{|c|}{ Ground corn } \\
\hline Dry matter $(\%)^{\mathrm{ns}}$ & 883.4 & 878.6 & 887.2 & 902.5 & 0.213 & 0.108 & 0.276 & 2.31 \\
\hline Crude protein $(\%)^{\mathrm{ns}}$ & 124.7 & 76.4 & 82.3 & 111.4 & 0.765 & 0.335 & 0.081 & 77.00 \\
\hline Mineral matter $(\%)^{\mathrm{ns}}$ & 27.3 & 14.7 & 26.4 & 16.6 & 0.507 & 0.633 & 0.226 & 74.11 \\
\hline Aflatoxins $(\mathrm{ppm})^{\mathrm{ns}}$ & 0.172 & 0.080 & - & - & 0.573 & 0.504 & 0.928 & 92.09 \\
\hline Zearalenone $(\mathrm{ppb})^{\mathrm{ns}}$ & 6.985 & 9.40 & - & - & 0.761 & 0.375 & 0.978 & 102.95 \\
\hline \multicolumn{9}{|c|}{ Trade feed } \\
\hline Dry matter $(\mathrm{g} / \mathrm{kg})^{\mathrm{ns}}$ & 901.5 & 895.1 & 914.7 & 911.3 & 0.058 & 0.085 & 0.062 & 7.11 \\
\hline Crude protein $(\mathrm{g} / \mathrm{kg})^{\mathrm{ns}}$ & 194.9 & 199.8 & 191.7 & 210.8 & 0.623 & 0.831 & 0.444 & 11.83 \\
\hline Mineral matter $(\mathrm{g} / \mathrm{kg})^{\mathrm{ns}}$ & 76.8 & 54.0 & 67.9 & 57.3 & 0.091 & 0.534 & 0.427 & 14.13 \\
\hline Aflatoxins $(\mathrm{ppm})^{\mathrm{ns}}$ & 0.162 & 0.127 & - & - & 0.607 & 0.576 & 0.365 & 81.96 \\
\hline Zearalenone $(\mathrm{ppb})^{\mathrm{ns}}$ & 14.457 & 5.207 & - & - & 0.223 & 0.727 & 0.704 & 42.44 \\
\hline \multicolumn{9}{|c|}{ Feed produced at the property } \\
\hline Dry matter $(\%)^{\mathrm{ns}}$ & 930.4 & 871.1 & 904.3 & 909.3 & 0.061 & 0.232 & 0.627 & 3.66 \\
\hline Crude protein $(\%)^{\mathrm{ns}}$ & 124.3 & 225.1 & 168.7 & 216.4 & 0.311 & 0.726 & 0.617 & 41.68 \\
\hline Mineral matter $(\%)^{\mathrm{ns}}$ & 54.5 & 40.3 & 54.8 & 57.1 & 0.247 & 0.118 & 0.074 & 34.74 \\
\hline Aflatoxins (ppm) $)^{\mathrm{ns}}$ & 0.132 & 0.225 & - & - & 0.616 & 0.585 & 0.765 & 108.42 \\
\hline Zearalenone $(\mathrm{ppb})^{\mathrm{ns}}$ & 10.75 & 3.29 & - & - & 0.072 & 0.097 & 0.076 & 70.52 \\
\hline \multicolumn{9}{|c|}{ Wet grain silage } \\
\hline Dry matter $(\mathrm{g} / \mathrm{kg})^{\mathrm{ns}}$ & 689.8 & 710.0 & 725.0 & 704.6 & 0.061 & 0.063 & 0.052 & 15.51 \\
\hline Crude protein $(\mathrm{g} / \mathrm{kg})^{\mathrm{ns}}$ & 109.5 & 88.6 & 81.3 & 94.9 & 0.136 & 0.077 & 0.169 & 11.24 \\
\hline Mineral matter (\%) & $42.5 \mathrm{a}$ & $13.4 b$ & $24.5 \mathrm{ab}$ & $16.5 \mathrm{ab}$ & 0.025 & 0.886 & 0.891 & 29.78 \\
\hline Aflatoxins $(\mathrm{ppm})^{\mathrm{ns}}$ & 0.076 & 0.089 & - & - & 0.927 & 0.882 & 0.982 & 124.91 \\
\hline Zearalenone $(\mathrm{ppb})^{\mathrm{ns}}$ & 2.633 & 24.00 & - & - & 0.067 & 0.063 & 0.123 & 97.5 \\
\hline
\end{tabular}

TA - technical assistance; $\mathrm{S}$ - season; TA $\times \mathrm{S}$ - technical assistance $\times$ season interaction; $\mathrm{CV}$ - coefficient of variation; ns - not significant.

Means followed by different letters in the line differ statistically by the Tukey test $(5 \%)$. 
Table 4 - Number of lactating animals per property (no. animals), total production per property (kg milk/day/property), mean production per animal (kg/day), milk composition, TBC and SCC in milk produced on household farms in western Paraná with and without technical assistance throughout the four seasons

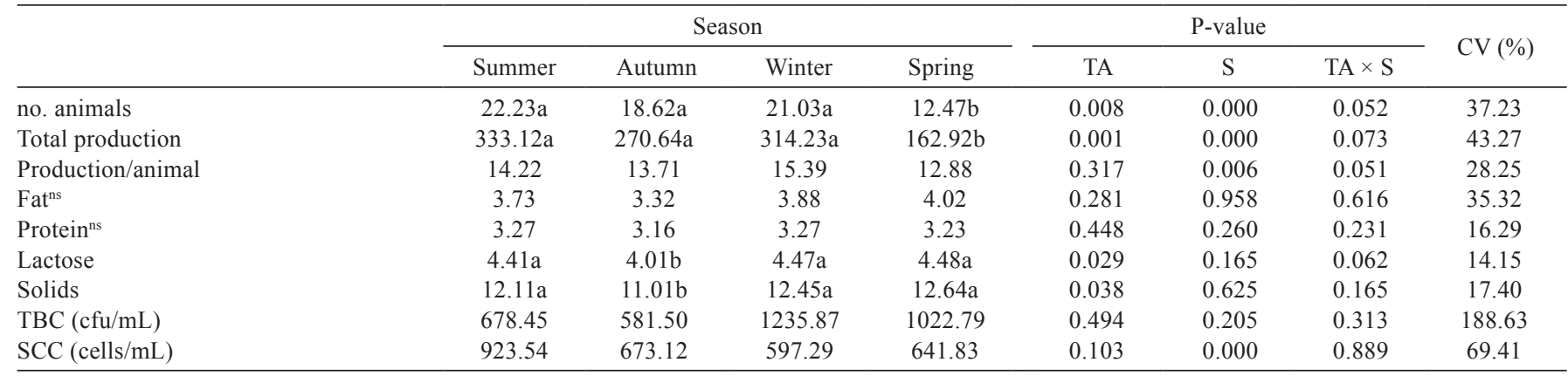

TA - technical assistance; S - season; TA $\times$ S - technical assistance $\times$ season interaction, CV - coefficient of variation; ns - not significant; TBC - total bacterial count; cfu - colony-forming units; SCC - somatic cell count.

Means followed by different letters in the row differ statistically by the Tukey test $(5 \%)$.

autumn, the period that follows the highest temperatures (Figure 1), there were absolute means of fat and protein lower than the means in other seasons. According to Nääs and Arcaro Júnior (2001), measures such as the adoption of artificial leftovers, water sprinklers and ventilation can ensure that the fat values remain constant during periods of high temperatures, when the percentage of milk components tends to reduce (Head, 1989). Lactose and total solids were affected by the seasons, with lower values in the autumn (Table 4). Lacerda et al. (2010) observed decreased concentration of lactose and total solids in the summer period compared with the winter, as observed in this study (Figure 1). Despite the statistical significance for the values of lactose and total solids for milk composition, both assisted and unassisted, the values remained within the standards proposed (normative statement) by IN 51-2002. According to IN 51, the minimum solids nonfat content is $8.4 \%$, fat is $3 \%$, and protein is $2.9 \%$ (Brasil, 2002).

According to Mattos and Pedroso (2005), nutrition is the main tool that producers can use to alter the milk composition, and such modifications have quick and effective results; the simple change of forage:concentrates ratio in the diet that can modify the fat content of milk to more than $15 \%$ and the availability of amino acids for protein synthesis by the mammary gland is determined by intestinal absorption. The more amino acids are absorbed the more substrate for synthesis of caseins and whey proteins. Protein molecules are nothing more than a predetermined sequence of amino acids.

The somatic cell count (SCC) was higher on the properties without assistance (898.71 cells/mL) as compared with those receiving assistance $(519.18$ cells $/ \mathrm{mL})$. The values were compared with the IN51-2002; properties with technical assistance had $\mathrm{SCC}$ and $\mathrm{TBC}$ values within the expected range, but the properties without assistance showed SCC values above that proposed by the IN 51 : 750,000 cells $/ \mathrm{mL}$. Intrinsic factors such as cow age, days in lactation, and breed, and extrinsic factors such as storage time of the sample and collection period (Barbosa et al., 2007) may affect the SCC, in addition to the presence of an intramammary infection. According to Lacerda et al. (2010), periods at high temperatures, high humidity and periodic rains facilitate the exposure of teats to a greater number of microorganisms, thus increasing the SCC.

Regarding TBC, although no statistical significance was observed, the values were low in summer and autumn, but higher than the IN 51-2002 for winter and spring, which determines a maximum limit of 750,000 cells $/ \mathrm{mL}$. As the rainfall was limited in these periods (Figure 1), the high $\mathrm{TBC}$ values can be attributed to the difficulties in cleaning the milking equipment. Failures in the management of preand/or post-dipping (Lacerda et al., 2010) like the use of wrong concentration, or the use of unsuitable products, can change the TBC values.

In addition, the properties that received assistance had training courses conducted with producers and hygiene training in the practice of milking with demonstration of pre- and post-dipping, CMT test and pitcher black background test, showing the importance of hygiene and cleaning the teats of cows for milk quality.

\section{Conclusions}

The technical assistance does not affect the quality of forages and concentrates used and the milk composition; however, it improves the sanitary quality of the milk produced throughout the four seasons in the household farms of western Paraná state of Brazil. 


\section{Acknowledgments}

The authors thank the partnership of Secretaria da Ciência, Tecnologia e Ensino Superior (SETI), and Instituto Paranaense de Assistência Técnica e Extensão Rural (EMATER) through the project Universidade Sem Fronteiras (USF).

\section{References}

ANVISA - Agência Nacional de Vigilância Sanitária. Ministério da Saúde. 2002. Resolução - RE no 140, de 9 de agosto de 2002. Diário Oficial da União; Poder Executivo, 12 de agosto de 2002.

AOAC - Association of Official Analytical Chemistry. 1990. Official methods of analysis. 13th ed. AOAC International, Washington, DC.

Barbosa, S. B. P.; Monardes, H. G.; Cue, R. I.; Ribas, N. P. and Batista, A. M. V. 2007. Avaliação da contagem de células somáticas na primeira lactação de vacas holandesas no dia do controle mensal. Revista Brasileira de Zootecnia 36:94-102.

Bittar, C. M. M.; Santos, F. A. P.; Moura, J. C. and Faria, V. P. 2011. Manejo alimentar de bovinos. 1.ed. FEALQ, Piracicaba.

Brasil. Instrução Normativa ${ }^{\circ} 51$, de 20 de setembro de 2002. Aprova os regulamentos técnicos de produção, identidade e qualidade do leite tipo... Diário Oficial da União, Brasília, p.13, 21 set. 2002.

Bruerton, K. 2001. Finding practical solutions to mycotoxins in commercial production: a nutritionist's perspective. p.161-168. In: Proceedings of the Alltech's 17th Annual Symposium. Queensland, Australia.

Calixto Junior, M.; Jobim, C. C. and Canto, M. W. 2007. Taxa de desidratação e composição químico-bromatológica do feno de grama-estrela (Cynodon nlemfuensis Vanderyst) em função de níveis de adubação nitrogenada. Semina: Ciências Agrárias 28:493-502.

Costa, N. L.; Gianluppi, V. and Moraes, A. 2012. Produtividade de forragem e morfogênese de Trachypogonvestitus, durante o período seco, em área de cerrado, Roraima, Revista Trópica - Ciências Agrárias e Biológicas 6:93-98.

Damasceno, J. C.; Bodenmüller Filho, A.; Ramos, C. E. C. O.; Santos Filho, J. C. and Santos, G. T. 2008. O papel do homem na gestão e controle de qualidade da produção de leite. p.271-284. In: Inovação tecnológica na cadeia produtiva do leite e a sustentabilidade da pecuária leiteira. Santos, G. T.; Uhlig, L.; Branco, A. F.; Jobim, C. C.; Damasceno, J. C. and Cecato, U., eds. Eduem, Maringá.

Domingues, J. L. 2009. Uso de volumosos concentrados na alimentação de equinos. Revista Brasileira de Zootecnia 38(supl. especial):259-269.

FAO - Food and Agriculture Organization of the United Nations. 1996. Worldwide regulations for mycotoxins, 1995. A compendium. Roma, n.64, p.9-20.

Fernandes, E. N.; Bressan, M. and Verneque, R. S. 2004. Zoneamento da pecuária leiteira da região sul do Brasil. Ciência Rural 34:485-491.

Gonçalves, S. L.; Caramori, P. H.; Wrege, M. S.;Shioga, P.; Gerage, C. A. 2002. Épocas de semeadura do milho "safrinha", no Estado do Paraná, com menores riscos climáticos. Acta Scientiarum 24:1287-1290.

Grieshop, C. M.; Kadzere, C. T.; Clapper, G. M.; Flickinger, E. A.; Bauer, L. L., Frazier, R. L. and Fahey, G. C. 2003. Chemical and nutritional characteristics of United States soybeans meals. Journal Agricultural Food Chemistry 51:7684-7691.

Guerreiro, P. K.; Machado, M. R. F.; Braga, G. C.; Gasparino, E. and Franzener, A. S. M. 2005. Qualidade microbiológica de leite em função de técnicas profiláticas no manejo de produção. Ciências Agrotécnicas 29:216-222.

Head, H. H. 1989. The strategic use of the physiological potential of the dairy cow. p.38-89. In: Anais do Simpósio Leite nos Trópicos: Novas estratégias de produção, Botucatu.

Henrique, W.; Beltrame Filho, A. J.; Leme, P. R.; Lanna, D. P. D.; Alleoni, G. F.; Coutinho Filho, J. L. V. and Sampaio, A. A. M. 2007. Avaliação da silagem de grãos de milho úmido com diferentes volumosos para tourinhos em terminação. Desempenho e características de carcaça. Revista Brasileira de Zootecnia $36: 183-190$

Jobim, C. C.; Branco, A. B. and Santos, G. T. 2003. Silagem de grãos úmidos na alimentação de bovinos leiteiros. p.357-376. In: Anais do 5o Simpósio Goiano sobre Manejo e Nutrição de Bovinos de Corte e Leite. Goiânia.

Jobim, C. C.; Nussio, L. G.; Reis, R. A. and Schmidt, P. 2007. Avanços metodológicos na avaliação da qualidade da forragem conservada. Revista Brasileira de Zootecnia 36:101-119.

Kramer, J. and Voorsluys, J. L. 1991. Silagem de milho úmido, uma

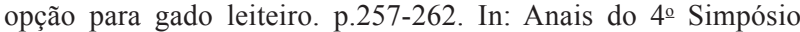
sobre Nutrição de Bovinos. Fundação de Estudos Agrários Luiz de Queiroz, Piracicaba.

Lacerda, L. M.; Mota, R. A. and Sena, M. J. 2010. Contagem de células somáticas, composição e contagem bacteriana total do leite de propriedades leiteiras nos municípios de Miranda do Norte, Itapecurú-Mirim e Santa Rita, Maranhão. Arquivos do Instituto Biologico 77:209-215.

Lazzari, F. A. 1997. Umidade, fungos e micotoxinas na qualidade de sementes, grãos e rações. 2.ed. [s.n.], Curitiba.

Mattos, W. and Pedroso, M. A. [2005] Como dieta afeta a composição do leite. Available at: <http://www.rehagro.com.br $>$ Accessed on: Aug. 19, 2012

McDonald, P.; Henderson, A. R. and Heron, S. J. E. 1991. The biochemistry of silage. 2.ed. Chalcombe Publications, Marlow.

Melo, W. M. C.; Von Pinho, R. G.; Carvalho, M. L. M. and Von Pinho, E. V. R. 1999. Avaliação de cultivares de milho para produção de silagem na região de Lavras, MG. Ciência e Agrotecnologia 23:31-39

Munck, A.; Guyre, P. M. and Holbrook, N. J. 1984. Physiological functions of glucocorticoids in stress and their relation to pharmacological actions. Endocrine Reviews 5:25.

Nããs, I. A. and Arcaro Júnior, I. 2001. Influência de ventilação e aspersão em sistemas de sombreamento artificial para vacas em lactação em condições de calor. Revista Brasileira de Engenharia Agrícola e Ambientalrande 5:139-142.

Paraná - Secretaria da Agricultura e do Abastecimento. Departamento de Economia Rural. 2010. Análise da conjuntura agropecuáriaLeite. Curitiba, SEAB.

Prado, G.; Mattos, S. V. M. and Pereira, E. C. 1991. Efeito da umidade relativa na contaminação microbiana e produção de aflatoxinas em amendoim em grão. Ciência e Tecnologia de Alimentos $11: 264-273$

Reis Junior, L. C. V.; Almeida, J. C. C.; Araújo, R. P.; Lista, F. N.; Ribeiro, E. T.; Mendonça, D. C.; Abreu, J. B. R.; Araújo, S. A. C. and Ribeiro, T. P. 2011. Qualidade do feno de capim coast-crosssob níveis de uréia e períodos de amonização. Revista de Ciências da Vida 31:71-80

Rieger, C.; Oliveira, W.; Lovatto, P. A.; Araújo, J. S.; Peixoto, E. C. T. M. and Silva, M. A. 2008. Características químicas e valores energéticos de farelos de soja do oeste e sudoeste do Paraná. Ciência Rural 38:266-269.

Rostagno, H. S.; Albino, L. F. T.; Donzele, J. L.; Gomes, P. C.; Oliveira, R. D.; Lopes, D. C.; Ferreira, A. S.; Barreto, S. L. T. and Euclides, R. F. 2005. Tabelas brasileiras para aves e suínos: 
composição de alimentos e exigências nutricionais. 2.ed. Editora UFV, Viçosa, MG.

Rupollo, G.; Gutkoski, L. C.; Martins, I. R. and Elias, M. C. 2006. Efeito da umidade e do período de armazenamento hermético na contaminação natural por fungos e a produção de micotoxinas em grãos de aveia. Ciência e Agrotecnologia 30:118-125.

Santos N. L.; Da Silva M. W. R. and Chave, S. M. A. 2008. Efeito da irrigação suplementar sobre a produção dos capins tifton 85 , tanzânia e marandu no período de verão no sudoeste baiano. Ciência Animal Brasileira 9:911-922.

Silva, D. J. and Queiroz, A.C. 2002. Análise de alimentos: métodos químicos e biológicos. Universidade Federal de Viçosa, Viçosa, MG.

Tomich, T. R.; Gonçalves, L. C.; Tomich, R. G. P.; Rodrigues, J. A. S.; Borges, I. and Rodriguez, N. M. 2004. Características químicas e digestibilidade in vitro das silagens de girassol. Revista Brasileira de Zootecnia 33:1672-1682.

Valadares Filho, S. C. 2000. Nutrição, avaliação de alimentos e tabelas decomposição de alimentos para bovinos. p.267-337. In: Anais da $37^{a}$ Reunião Anual da Sociedade Brasileira de Zootecnia. Sociedade Brasileira de Zootecnia, Viçosa, MG.

Van Soest, P. J.; Robertson, J. B. and Lewis, B. A. 1991. Methods for dietary fiber, neutral detergent fiber, and nonstarch polysaccharides in relation to animal nutrition. Journal of Dairy Science 74:3583-3597.

Volpi, R. and Digiovani, M. S. C. 2008. Aspectos econômicos da produção paranaense de leite, dados estatísticos e tendências de mercado. p.21-35. In: Inovação tecnológica na cadeia produtiva do leite e a sustentabilidade da pecuária leiteira. Santos, G. T.; Uhlig, L.; Branco, A. F.; Jobim, C. C.; Damasceno, J. C. and Cecato, U., eds. Eduem, Maringá.

Wittenberg, K. M.; Undi, M. and Bossuyt, C. 1996. Establishing a feed value for moulded hay. Animal Feed Science and Technology 60:301-310.

Yamaguchi, L. C. T.; Martins, P. C. and Zoccal, R. 2006. Dinâmica da produção de leite no Brasil no período de 1990 a 2004. Qualidade e eficiência na produção de leite. 1.ed. v.1. Embrapa Gado de Leite, Juiz de Fora.

Zoccal, R.; Souza, A. D.; Gomes, A. T.; Leite, J. L. B. [2005] Produção de leite na agricultura familiar. Available at: <http://www.sober. org.br/palestra/12/09O433.pdf> Accessed on: May 29, 2012.

Zambom, M. A.; Santos, G. T.; Modesto, E. C.; Alcalde, C. R.; Gonçalves, G. D.; Silva, D. C.; Silva, K. T. and Faustino, J. O. 2001. Valor nutricional da casca do grão de soja, farelo de soja, milho moído e farelo de trigo para bovinos. Acta Scientiarum 23:937-943. 